\title{
Global Reporting Initiative Index Sebagai Model Pengukuran Triple Bottom Line Pada Industri Kategori Environment High Risk (Studi Komparasi Indonesia Dan Malaysia)
}

\author{
Moh. Ritanto Gobel, Djoko Sigit S, Adi Prasetyo \\ Program Studi Akuntansi Fakultas Ekonomi dan Bisnis \\ Universitas Muhammadiyah Malang \\ Jl. Raya Tlogomas No.246 Malang
}

\begin{abstract}
This research aims to describe the parctice of Triple Bottom Line Disclosure to the industries whose the category is environment high risk in Indonesia and Malaysia which is reviewed by Index Model GRI and explain the aspects that differ the practice of Triple Bottom Line Disclosure at environment high risk category in Indonesia and Malaysia which is reviewed by Index GRI model. This research used Content Analysis and Mann-Whitney Test. The result of this research shows that there are still many items of triple bottom line componen that have not been shown yet. The significance of differences of Triple Bottom Line Disclosure about Malaysian industry and Indonesia shows the point 64\% from Indonesia and 36\% from Malaysia and there is some difference between Triple Bottom Line Disclosure of Malaysian industry and Indonesian industry.
\end{abstract}

Keywords: index GRI, Triple Bottom Line, Environment High Risk.

\section{PENDAHULUAN}

Salah satu informasi yang sering diminta untuk diungkapkan perusahaan saat ini adalah informasi tentang tanggung jawab sosial perusahaan. Tanggung jawab sosial perusahaan terhadap lingkungan dan masyarakat menjadi salah satu isu yang menarik dalam dunia bisnis. Perusahaan dituntut tidak hanya mementingkan kepentingan operasionalnya dalam hal ini kaitannya dengan bisnis, melainkan harus mementingkan kepentingan sosial kemasyarakatan dan lingkungan sekitar, hal ini diatur dalam undang-undang No. 40 tahun 2007 pasal 74 ayat 1 yaitu "perseroan yang menjalankan kegiatan usahanya dibidang dan/atau berkaitan dengan sumber daya alam wajib melaksanakan tanggung jawab sosial dan lingkungan".

Konsep CSR juga terdapat dalam ajaran islam. Islam mengajarkan bahwa tidak cukup bagi seorang muslim hanya memfokuskan diri beribadah kepada $\mathrm{Al}-$ lah. Dalam islam, manusia merupakan Khalifah dimuka bumi, sehingga manusia juga harus menyemarakkan kebaikan kepada sesama makhluk ciptaan-Nya, oleh sebab itu kesempurnaan iman seorang muslim tidak dapat hanya dicapai dengan hubungan vertikal kepada Allah saja (Hablumminallah), tetapi harus dibarengi dengan hubungan yang baik kepada sesama makhluk ciptaan Allah (Hablumminannas) (Alqur'anul Karim Surat Al-ma'un ayat 1-7).

Jika perusahaan mau mempertahankan keberlangsungan perusahaan (Going Concern) dalam jangka panjang, kondisi keuangan saja tidak cukup menjamin nilai perusahaan tumbuh secara berkelanjutan (Sustainable). Untuk memudahkan tercapainya pembangunan keberlanjutan, perusahaan tidak lagi dihadapkan pada tanggung jawab yang berpijak pada konsep Single Bottom Line, yaitu nilai perusahaan (Corporate Value) yang direfleksikan dalam kondisi eko-

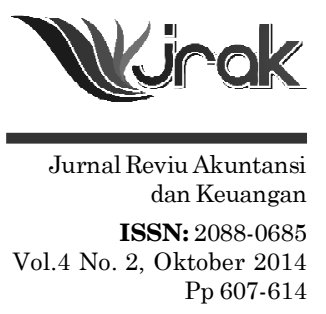


Global

Reporting

Initiative

Index...

608 nomi (Financial/profit) saja tetapi lebih berpijak pada konsep Triple Bottom Line yang telah mencakup seluruh aspek kegiatan perusahaan yang seharusnya yaitu profit (economic), people (social), dan planet (environment) (Rustiarini,2010). Praktek pengungkapan dari kategori dalam konsep Triple Bottom Line dalam setiap industri kemungkinan besar berbeda. Bentuk perusahaan yang biasanya melaksanakan program CSR adalah perusahaan yang menjalankan kegiatan usahanya dibidang dan atau berkaitan dengan sumber daya alam, seperti; perusahaan pertambangan, manufaktur terutama kimia dasar dan tekstil atau garment, perkebunan, dan industri konstruksi (Sari, 2012).

Dari segi aktivitasnya, industri pertambangan, industri manufaktur dasar dan kimia, perkebunan, dan konstruksi juga oleh European Bank For Reconstruction and Development (EBRD) disebut-sebut sebagai industri yang paling banyak merugikan masyarakat dan lingkungan sekitarnya. EBRD merupakan suatu lembaga international di eropa yang berupaya untuk mengembangkan iklim investasi yang sehat didasarkan pada kerangka hukum dan peraturan yang efektif dan mempromosikan tata kelola perusahaan, termasuk praktek-praktek manajemen yang baik, sikap tegas terhadap praktek korupsi, keterbukaan informasi akuntansi serta praktek audit yang jelas. Dalam standar EBRD revisi tahun 2014 ini mengungkapkan bahwa dari seluruh sektor industri yang ada, yang termasuk industri dengan high risk level of social and Environment adalah industri pertambangan, perkebunan dan manufaktur terutama kategori perusahaan yang bergerak dalam bidang kimia dasar (EBRD; 2014).

Indonesia mempunyai penduduk sebanyak 250 juta jiwa, $11 \%$ nya adalah jumlah penduduk yang berpendapatan rendah atau miskin. Jumlah angkatan kerja di indonesia pada tahun 2013 mencapai 121,2 juta orang 48\% nya adalah pekerja yang hanya memiliki jenjang pendidikan SD (Biro Pusat Statistik,2013). Indonesia menghadapi masalah sosial yang cukup parah, seperti masalah isu HAM yaitu mempekerjakan anak dibawah umur, gaji rendah dan korupsi (Setyawanti dkk,2013). Malaysia mempunyai penduduk sekitar 27,17 juta jiwa, juga menghadapi masalah sosial yang serupa dengan indonesia, walaupun dalam dua dekade terakhir yaitu tahun 1980-an dan tahun 1990-an mencatat pertumbuhan ekonomi yang cukup pesat (mencapai GDP diatas 7\%). Kemajuan perekonomian di kedua negara ternyata membawa dampak terhadap lingkungan sosial. Perusahaan yang selama ini telah menjadi agen pertumbuhan ekonomi tampaknya harus mulai memikirkan para stakeholder dan juga lingkungan sosialnya (Setyawanti $\mathrm{dkk}, 2013)$.

Penelitian tentang Triple Bottom Line sangat menarik untuk diteliti, melihat pada isu-isu sekarang perusahaan dituntut tidak hanya mementingkan nilai perusahaan yang direfleksikan dalam kondisi ekonomi (Financial/profit) tetapi lebih berpijak pada konsep Triple Bottom Line yang telah mencakup seluruh aspek kegiatan perusahaan yang seharusnya yaitu Profit (economic), People (social), dan planet (environment). Triple Bottom Line dalam penelitian ini diukur dengan menggunakan standar Global Reporting Initiative Index (selanjutnya disingkat index GRI). Maka dari itu, penelitian ini dimaksudkan untuk menganalisa sejauh mana luas pengungkapan triple bottom line dalam sustainability report pada industri kategori environment high risk di Indonesia jika dibandingkan dengan industri di Malaysia.

Berdasarkan pernyataan diatas dalam penulisan karya akhir ini, peneliti tertarik mengangkat penulisan ini dengan judul "Global Reporting Initiative Index: sebagai Model Pengungkapan Triple Bottom Line pada Industri Kategori Environment High Risk (Srudi Komparasi Indonesia dan malaysia)". Tujuan dalam penelitian ini adalah mendeskripsikan dan menela'ah praktik pengungkapan Triple Bottom Line pada industri kategori environment high risk di Indonesia dan Malaysia yang ditinjau dengan model index GRI dan menjelaskan ada atau tidaknya perbedaan pengungkapan serta menjelaskan aspek yang membedakan praktek pengungkapan Triple bottom Line pada industri kategori environment high risk di Indonesia dan Malaysia yang ditinjau dengan model index GRI. 
Jenis penelitian ini merupakan penelitian deskriptif komparatif yaitu mengungkapkan, menjelaskan atau menggambarkan suatu fenomena secara sistematis dan menjelaskan ada atau tidaknya perbandingan dalam suatu fenomena tersebut. Penelitian menela'ah dan mendeskripsikan secara luas tentang perbedaan praktek pengungkapan triple bottom line pada industri kategori environment high risk di negara Indonesia dan Malaysia sesuai dengan standar GRI.

Populasi dalam penelitian ini adalah industri yang masuk kedalam kategori environment high risk yang terdaftar di Bursa Efek Indonesia (BEI) dan Bursa Malaysia. Metode pengambilan sampel menggunakan metode purposive sampling, dimana memenuhi kriteria sebagai berikut: industri kategori environment high risk yang terdaftar di Bursa Efek Indonesia maupun di Bursa Malaysia dan industri yang menerbitkan Sustainability Report periode 2013.

Jenis data yang digunakan dalam penelitian ini adalah data sekunder yaitu data yang diperoleh dari pihak lain dalam bentuk data yang sudah jadi atau berupa publikasi atau data berupa hasil dokumentasi dan arsip-arsip resmi berupa Sustainability Report. Data penelitian ini adalah data tentang informasi dari setiap kategori Economic (profit), Social (people), dan Environment (planet) yang dilihat dari setiap indikatornya sesuai dengan standar Global Reporting Initiative (GRI) baik industri di Indonesia dan Malaysia. Peneliti mengumpulkan data dengan metode dokumentasi dan observasi tidak langsung dalam memperoleh data perusahaan yang dikelompokkan pada tiga kategori dalam triple bottom line. Dokumentasi ini dilakukan dengan cara mengumpulkan, menggandakan, serta menyalin data berupa informasi keuangan dan non keuangan yang dibutuhkan. Sedangkan teknik observasi tidak langsung dilakukan dengan cara melakukan teknik content analysis pada sustainability report perusahaan.

Teknis analisis data menggunakan Content analysis. Metode ini digunakan untuk menjawab praktek pengungkapan triple bottom line pada industri kategori environment high risk di Indonesia dan Malaysia. Analisis ini dilakukan dengan cara pemberian checklist. Pemberian checklist dilakukan pada item yang diungkapkan di dalam laporan tersebut. Setelah dilakukan checklist, maka item yang diungkapkan dalam sustainability report diatas akan diberikan nilai "1" (satu) dan jika tidak diungkapkan maka akan diberi nilai "0" (nol).

Uji mann-whitney digunakan untuk membandingkan dua sampel yang tidak berhubungan. Uji mann-whitney dipilih karena uji mann- whitney merupakan uji terkuat yang digunakan sebagai alternatif uji parametrik $\mathrm{T}$ test. Teknik ini merupakan uji non parametrik yang digunakan untuk membandingkan skor pengungkapan triple bottom line antara industri kategori environment high risk di Indonesia dan Malaysia.

\section{HASIL DAN PEMBAHSAN}

Dibawah ini telah disajikan hasil pengujian mann-whitney test untuk menilai perbedaan pengungkapan mulai dari perbedaan pengungkapan dari setiap indikator triple bottom line yaitu economic performance, social performance, dan environment performance serta perbedaan pengungkapan triple bottom line secara keseluruhan dalam sustainability report pada perusahaan di Indonesia dan $\mathrm{Ma}^{-}$ laysia.

\begin{tabular}{lccc}
\hline \multicolumn{1}{c}{ NEGARA } & OBS & RANK SUM & EXPECTED \\
\hline INDONESIA & 9 & 110.5 & 85.5 \\
MALAYSIA & 9 & 60.5 & 85.5 \\
COMBINED & 18 & 117 & 117 \\
\hline
\end{tabular}


Global

Reporting

Initiative

Index...

610

Tabel 2

Hasil Uji

Mann-whitney

Social Performance
Unadjusted Variance 128.25

Adjustment for ties $\underline{-10.59}$

Adjusted Variance 117.66

Ho: Economic $($ Negara $==$ Indonesia $)=$ Economic $($ Negara $==$ Malaysia $) \mathrm{Z}=2.305$

Prob $>|\mathrm{Z}|=0.0212$

Berdasarkan hasil uji mann-whitney pada table 1 untuk kategori economic performance menujukkan terdapat perbedaan pada pengungkapan komponen economic performance. Hal ini dibuktikan dengan nilai $\mathrm{Z}$ sebesar 2.305 dengan $\mathrm{P}$ Value (prob $>|z|$ ) sebesar 0,0212. Artinya, nilainya kurang dari 0,05, sehingga rata-rata pengungkapan economic performance pada perusahaan Indonesia dan perusahaan Malaysia berbeda.

\begin{tabular}{lccc}
\hline \multicolumn{1}{c}{ NEGARA } & OBS & RANK SUM & EXPECTED \\
\hline INDONESIA & 48 & 2566 & 2328 \\
MALAYSIA & 48 & 2090 & 2328 \\
COMBINED & 96 & 4656 & 4656 \\
\hline
\end{tabular}

Unadjusted Variance 18624.00

Adjustment for ties $\underline{-2547.16}$

Adjusted Variance 16076.84

Ho: Social $($ Negara $==$ Indonesia $)=$ Social $($ Negara $==$ Malaysia $)$

$\mathrm{Z}=1.877$

$\operatorname{Prob}>|\mathrm{Z}|=0.0605$

Hasil uji mann-whitney pada komponen social performance menunjukkan tidak terdapat perbedaan pada pengungkapan komponen ini. Dibuktikan dengan nilai probabilitas 0,0605 yang lebih besar dari 0,05.

\begin{tabular}{lccc}
\hline \multicolumn{1}{c}{ NEGARA } & OBS & RANK SUM & EXPECTED \\
\hline INDONESIA & 34 & 1608 & 1173 \\
MALAYSIA & 34 & 2090 & 1173 \\
COMBINED & 68 & 4656 & 2346 \\
\hline
\end{tabular}

Unadjusted Variance 6647.00

Adjustment for ties -748.38

Adjusted Variance 5898.62

Ho: Environment $($ Negara $==$ Indonesia $)=$ Environment $($ Negara $==$ Malaysia $) \mathrm{Z}=$ 5.664

Prob $>|\mathrm{Z}|=0.0000$

Dari tabel hasil uji mann-whitney untuk kategori environment performance menujukkan bahwa komponen tersebut antara Industri di Indonesia dan Industri di malaysia memiliki tingkat perbedaan yang signifikan. Hal ini dibuktikan dengan adanya nilai probabilitas 0,0000 yang lebih kecil dari 0.05.

Dibawah ini akan disajikan hasil uji mann-whitney untuk menilai tingkat perbedaan pengungkapan triple bottom line secara keseluruhan mencakup tiga komponen yang telah dijelaskan diatas antara industry Indonesia dan industri Malaysia.

Unadjusted Variance 126285.25 


\begin{tabular}{lccc}
\hline \multicolumn{1}{c}{ NEGARA } & OBS & RANK SUM & EXPECTED \\
\hline INDONESIA & 91 & 10291.5 & 8326.5 \\
MALAYSIA & 91 & 6361.5 & 8326.5 \\
COMBINED & 182 & 16653 & 16653 \\
\hline
\end{tabular}

Adjustment for ties $\underline{-12342.06}$

Adjusted Variance 113943.19

Ho: TBL $($ Negara $==$ Indonesia $)=$ TBL $($ Negara $==$ Malaysia $) \mathrm{Z}=5.821$

Prob $>|\mathrm{z}|=0,0000$

Tabel 4

Hasil $U j i$

Mann-Whitney

Triple Bottom Line

Berdasarkan hasil dari pengujian mann-whitney seperti yang terlihat pada tabel 4.13 nilai $\mathrm{Z}$ menunjukkan nilai sebesar 5,821 dan nilai probabilitas $\mathrm{Z}$ menunjukkan nilai 0,0000 serta pada bagian bawah prob $>\mid \mathrm{z}=0,0000$ tertulis kata. Artinya nilai hitung lebih kecil dibandingkan dengan nilai á $=0,05$. Sehingga dapat disimpulkan bahwa pengungkapan triple bottom line pada sustainability report setiap Industri di dua negara terdapat perbedaan, dan pada gambar 4.1 menunjukkan persentase pengungkapan triple bottom line antar Industri di Indonesia dan Malaysia yang berdasarkan pada uji mann-whitney.

Pada bagian ini, peneliti mengkaji perbedaan pengungkapan triple bottom line antar industri kategori environment high risk di Indonesia dan Malaysia. Terlihat dari hasil uji mann-whitney perbedaan pengungkapan triple bottom line antar industri environment high risk di dua negara memiliki perbedaan yang sangat signifikan dengan nilai persentase keseluruhan triple bottom line untuk environment high risk Indonesia sebesar $64 \%$ dan environment high risk di Malaysia sebesar $36 \%$.

Jika ditelusuri secara mendalam dari hasil persentase ini, persentase tersebut merupakan representatif dari kinerja ekonomi, kinerja sosial, dan kinerja lingkungan yang sudah menampilkan hasil perbedaan yang jauh. Seperti yang sudah dibahas sebelumnya, komponen kinerja ekonomi pada industri environment high risk di Malaysia ada 3 (tiga) item yang tidak diungkapkan ialah item EC4 tentang bantuan finansial yang diterima dari pemerintah, EC5 tentang rasio upah standar pegawai pemula menurut gender dibandingkan dengan upah minimum regional di lokasi-lokasi operasional dan EC7 berisi tentang pembangunan dan dampak dari investasi infrastruktur dan jasa yang diberikan, hal tersebut dikarenakan kesediaan perusahaan melaporkan kinerja ekonomi masih minim. item EC1 menjadi satu-satu nya item yang diungkapkan oleh ketiga industri environment high risk industri di Malaysia karna item tersebut merupakan item yang berkaitan dengan aktivitas operasional rutin perusahaan seperti nilai ekonomi yang diterima atau penjualan/pendapatan dan nilai yang didistribusikan seperti pengeluaran/ beban operasional. Sementara environment high risk di Indonesia, hampir semua industri mengungkapkan item dari komponen kinerja ekonomi ini, karena industri tersebut memang betul-betul berfokus untuk meningkatkan kinerja ekonomi agar memiliki citra yang baik dimata investor. Jika di persentasikan pada komponen kinerja ekonomi, industri environment high risk Indonesia memperoleh hasil sebesar $81 \%$ sementara environment high risk di Malaysia memperoleh hasil sebesar $41 \%$.

Pada komponen kinerja lingkungan, hampir sama perbedaan signifikan pengungkapannya dengan kinerja ekonomi. Industri Environment high risk Indonesia memperoleh persentase sebesar $85 \%$ sementara industri environment high risk di Malaysia hanya 33\% hal ini dikarenakan minimnya pengungkapan kinerja lingkungan pada environment high risk di Malaysia serta ada beberapa item dari komponen kinerja lingkungan yang tidak diungkapkan seperti EN1, EN9, EN10, EN20, EN21, EN25, EN28, EN30, EN31, dan EN33. 
Global

Reporting

Initiative

Index...
Sementara pada komponen kinerja sosial persentase pengungkapannya tidak begitu jauh, yakni hanya berkisar 56\% untuk industri environment high risk Indonesia dan $42 \%$ untuk industri environment high risk di Malaysia. hal ini disebabkan karna ketiga industri environment high risk di Indonesia dan Malaysia memiliki pengungkapan yang minim bahkan ada beberapa item yang tidak diungkapkan oleh industri environment high risk di Malaysia. Hasil ini mendukung penelitian Setyawanti, dkk (2013) yang menyatakan bahwa kedua negara menghadapi masalah sosial yang cukup parah, seperti masalah isu HAM yaitu mempekerjakan anak dibawah umur, gaji rendah dan korupsi, serta laporan yang diterbitkan oleh European Bank for Reconstruction and Development (2014) yang menyatakan industri perkebunan, pertambangan, manufaktur industri dasar dan kimia disebut-sebut sebagai industri yang ber-status high risk level of social and Environment.

\section{SIMPULAN}

Berdasarkan hasil penelitian yang telah dilaksanakan, dapat disimpulkan bahwa kesadaran perusahaan terhadap aspek sosial dan lingkungan masih rendah yang dibuktikan bahwa perusahaan masih berfokus pada aspek financial, pada perusahaan Malaysia masih banyak item-item dari komponen triple bottom line yang masih belum diungkapkan, hal ini terbukti dari skor pengungkapan pada analisis content, hasil dari perhitungan persentase menunjukkan perbedaan yang signifikan pada pengungkapan triple bottom line antara Industri di Indonesia dan Industri di Malaysia yang menunjukkan nilai sebesar 64\% dari Indonesia dan 36\% dari Malaysia, hasil uji mann-whitney menunjukkan bahwa terdapat perbedaan yang signifikan pada pengungkapan triple bottom line antara industri di Indonesia dan industri. Hal ini dibuktikan dengan hasil nilai $\mathrm{Z}$ sebesar 5,821 dan nilai probabilitas menunjukkan kurang dari 0,05 yakni 0,0000.

Keterbatasan dalam penelitian ini adalah metode penelitian yang dipilih content analysis, sehingga potensi subjektifitas peneliti sangat tinggi saat melakukan checklist terhadap item triple bottom line, item yang dianalisis merupakan terapan dari standar GRI, meskipun upaya untuk menginterpretasikan setiap item telah dilakukan seteliti mungkin, namun masih ada kemungkinan terjadi kekurangan dalam interpretasi tersebut, penelitian ini hanya menguji sebanyak 6 (enam) objek penelitian yang dikomparasikan antara dua negara yakni 3 (tiga) di Indonesia dan 3 (tiga) di Malaysia, dikarenakan sulitnya bagi peneliti menemukan laporan sustainability report. Sehingga, jumlah objek penelitian sedikit hasil dari penelitian ini masih kurang merepresentasikan keadaan yang sebenarnya pada perusahaan di dua negara tersebut, penelitian ini hanya menguji perbedaan praktik pengungkapan triple bottom line pada industri di dua negara tersebut tanpa mengidentifikasi lebih lanjut faktor penyebabnya dikarenakan peneliti tidak memiliki data yang mendukung dan penelitian ini tidak mempertimbangkan sama atau tidak nya ukuran perusahaan yang dibandingkan, dikarenakan data keuangan industri di dua negara disajikan dalam mata uang masing-masing negara. Sehingga sulit bagi peneliti mengidentifikasi nilai kurs pada masa itu.

Saran yang dapat dipertimbangkan untuk peneliti berikutnya sebaiknya menambahkan jumlah sampel atau objek penelitian pada penelitian terkait triple bottom line, mempertimbangkan adanya ukuran perusahaan yang sama, serta melakukan konfirmasi terhadap pihak perusahaan yang dituju baik perusahaan di Indonesia maupun perusahaan di Malaysia secara online melalui $E$-mail atau secara langsung survey (wawancara/kuisioner) ke perusahaan sehingga dapat dilakukan pembahasan secara lebih mendalam. 
Aulia, Sandra. 2011. Analisis Pengungkapan Triple Bottom Line dan Faktor yang Mempengaruhi nya: Lintas Negara Indonesia dan Jepang. Thesis. Program Vokasi Akuntansi Universitas Indonesia TB Mh Idris Kartawijaya.

An Association of Australia's Senior Finance Executives From The Nation's Business Enterprises. 2003. Sustainability: A Guide to Triple Bottom Line Reporting. Group of Incorporated. Melbourne.

European Bank For Rescontruction and Development. EBRD Environment and

Social Risk Categorisation List-2014. http://www.adb.org/sites/default/files/linkeddocuments/45230-001-arm-esms.pdf. (diakses pada 20 Februari 2015).

Elkington, John. 1997. Cannibal With Forks: The Triple Bottom Line of 21st Century Business. Capstone, Oxford.

Fitria, Soraya \& Dwi Hartanti. 2010. Islam dan Tanggung Jawab Sosial: Studi Perbandingan Pengungkapan Berdasarkan Global Reporting Initiative Indeks dan Islamic Social Reporting Index. Simposium Nasional Akuntansi XIII. Purwokerto.

Gray, R.,D. Owen \& C. Adams. 1996. Accounting and Accountability: Change and Chalange Incorporate Social and Environmental Reporting. Prentice Hall. New York.

Global Reporting Initiative. 1997. Sustainability Reporting Guidelines. Version 3.0

Lako, Andreas. 2011. Deskontruksi Corporate Social Responsibility (CSR) \& Reformasi Paradigma Bisnis dan Akuntansi. Jakarta: Erlangga.

Limijaya, Amelia \& Felisia. 2014. Triple Bottom Line dan Sustainability. Volume

18 Nomor 1. Bina Ekonomi Majalah Ilmiah Fakultas Ekonomi Unpar. Fakultas Ekonomi Universitas Katolik Parahyangan.

Madura, Jeff. 2001. Pengantar Bisnis. Edisi 2. Jakarta: Salemba Empat.

Nurfajriyah. 2010. Implementasi Konsep Triple Bottom Line pada PT. Pertamina (Persero). Thesis. UIN Sunan Kalijaga Yogyakarta.

Rustiarini, Ni wayan. 2010. Pengaruh Corporate Governance pada Hubungan Corporate Social Responsibility dan Nilai Perusahaan. Simposium Nasional Akuntansi XIII. Puwokerto. Universitas Mahasaraswati Denpasar.

Syakhroza, Akhmad. 2005. Corporate Governance: Sejarah dan Perkembangan, Teori, Model, dan Sistem Governance serta Aplikasinya pada Perusahaan BUMN. Jakarta: Lembaga Penerbit FEUI.

Slaper, T.F \& Hall, T.J. 2011. The Triple Bottom Line: What is it and how does it works?. Indiana Business Review. Spring 2011.

Setyawanti Dandang, Djoko Suhardjanto \& Hanung Triatmoko. 2013. Praktek Social Disclosure (Kajian Komparatif Indonesia - Malaysia). Simposium Nasional Akuntansi. Manado.

Solihin, Ismail. 2009. Corporate Responsibility: From Charity to Sustainability.

Edisi Kedua. Jakarta: Salemba Empat.

Sari, Anggita. 2012. Pengaruh Karakteristik Perusahaan Terhadap Corporate Social Responsibility Disclosure pada Perusahaan Manufaktur yang Terdaftar di Bursa Efek Indonesia. Jurnal Nominal Volume 1 Nomor 1. Universitas Negeri Yogyakarta.

Suartana, I Wayan. 2010. Akuntansi Lingkungan dan Triple Bottom Line Accounting: Paradigma Baru Akuntansi Bernilai Tambah. Jurnal Bumi Lestari Volume 10 Nomor 1. Hlm 105 - 112. FE UNUD.

Sukaharsono, Eko Ganis. 2010. Metamorfosis Akuntansi Sosial dan Lingkungan: Mengkonstruksi Akuntansi Sustainabilitas Berdimensi Spiritualitas. Working Paper. Universitas Brawijaya Malang. 
